\title{
COMPARISON OF THE PROTEIN FRACTIONS OF FINGER MILLET
}

\author{
Geeta Ramachandra, Tumkur K. Virupaksha* and M. Shadaksharaswamy $\dagger$ \\ Department of Biochemistry, University of Agricultural Sciences, G.K.V.K. Campus, Bangalore-560065; and \\ $\nmid$ Department of Chemistry, Bangalore University, Bangalore-560001, India
}

(Revised 4 March 1978)

Key Word Index-Eleusine coracana;Gramineae, protein fractions; electrophoresis; MW distribution; amino acid composition; varietal differences.

\begin{abstract}
Sodium dodecyl sulphate-polyacrylamide gel electrophoresis (SDS-PAGE) has been employed to resolve protein subunits of finger millet (Eleusine coracana) varieties according to their MW. These studies have established that varietal differences exist in the protein composition of finger millet varieties. The MW distribution of the protein subunits in the albumin-globulin, prolamin and glutelin fractions show many differences between the parental and cross-bred varieties and these differences are greater in the albumin-globulin and glutelin fractions than in the prolamin fraction. The amino acid compositions of the protein fractions show some differences between varieties.
\end{abstract}

\section{INTRODUCTION}

Characterization of the storage proteins of cereals is important for several reasons, including breeding nutritionally superior varieties. Several studies have established that in corn [1] and in barley [2] the differences between proteins of normal and high-lysine varieties are due to a change in the proportions of the protein fractions in these cereals. It would be of interest to establish the relationship between variations in the amino acid composition and changes in protein fractions in other cereals and millets as well.

Varietal differences in the amino acid composition of finger millet (Eleusine coracana Gaertn.), an important food crop of India and Africa, have been established [3]. Solubility fractionation of the endosperm proteins of finger millet samples revealed that the white-grain varieties had a higher prolamin content than the browngrain varieties and the reverse relationship is true for the glutelin fraction. Among the lines derived from the crossing of a brown variety (Purna) with a white variety (Hamsa) of finger millet, some had higher levels of lysine than either of the parent varieties [3]. Therefore, it was of interest to study the amino acid composition and protein patterns of a few representative whitegrain and brown grain varieties of finger millet. This paper describes the SDS-PAGE of the Landry-Moureaux protein fractions of 5 varieties of finger millet and the amino acid composition of these protein fractions.

\section{RESULTS AND DISCUSSION}

The finger millet samples used in this investigation consisted of a pure line white-grain variety (Hamsa), a pure line brown-grain variety (Purna), two brown lines (HPB 20-5 and HPB 23-6) and one white line (HPW 83-4) derived from white and brown seed crosses (Hamsa $\times$ Purna).

It is customary to use 5 solvent systems in the LandryMoureaux extraction procedure to obtain 5 protein fractions. These are designated as albumin-globulin (solvent: saline, followed by water); true prolamin
$(70 \%$ iso $\mathrm{PrOH}) ;$ prolamin-like $(70 \%$ iso $\mathrm{PrOH}-0.6 \%$ mercaptoethanol (ME); glutelin-like (borate buffer, $\mathrm{pH}$ $10,0.5 \mathrm{M} \mathrm{NaCl}, 0.6 \% \mathrm{ME}$ ) and true glutelin (borate buffer pH 10, 0.5 M NaCl, 0.6\% ME, 0.5\% SDS) [4]. When finger millet proteins were fractionated by this procedure the isopropanol-ME soluble fraction (prolamin-like) and borate buffer-ME-SDS soluble fraction (true glutelin), were quantitatively the most important fractions [3]. Therefore, the extraction procedure was modified to obtain only 3 fractions [3], designated as albumin-globulin (Fraction I, extracted by $0.5 \mathrm{M} \mathrm{NaCl}$ and water), prolamin (Fraction II, extracted by $70 \%$ is $o$ PrOH $-0.6 \% \mathrm{ME}$ ) and glutelin (Fraction III, extracted by borate buffer, $\mathrm{pH} 10,0.5 \mathrm{M} \mathrm{NaCl}, 0.6 \% \mathrm{ME}, 0.5 \%$ SDS). The distribution of nitrogen in the 3 protein fractions from the 5 varieties of finger mullet are shown in Table 1. These fractions were subjected to SDS-PAGE and amino acid analyses.

\section{Electrophoretic comparison of protein fractions}

SDS-PAGE patterns of the protein components present in the 3 protein fractions of 5 finger millet varieties are shown in Figs $1-3$. The 3 protein fractions of all finger millet varieties are heterogeneous and consist of several protein components with a range of $\mathrm{MW}$

Table 1. Distribution of nitrogen in the protein fractions extracted from finger millet varieties*

\begin{tabular}{|c|c|c|c|c|c|}
\hline Fraction & Hamsa & Purna & $\begin{array}{c}\text { Variety } \\
\text { HPW } \\
83-4\end{array}$ & $\begin{array}{c}\text { HPB } \\
20-5\end{array}$ & $\begin{array}{l}\text { HPB } \\
23-6\end{array}$ \\
\hline $\begin{array}{l}\text { Fraction } 1 \\
\text { (albumin- } \\
\text { globulin) }\end{array}$ & 9.6 & 12.1 & 9.8 & 11.1 & 12.2 \\
\hline $\begin{array}{l}\text { Fraction II } \\
\text { (prolamin) }\end{array}$ & 29.0 & 22.1 & 25.8 & 29.0 & 29.7 \\
\hline $\begin{array}{l}\text { Fraction III } \\
\text { (glutelin) }\end{array}$ & 14.5 & 14.6 & 16.1 & 14.5 & 16.2 \\
\hline $\begin{array}{l}\text { Total N } \\
\text { extracted }\end{array}$ & 53.1 & 48.8 & 51.7 & 54.6 & 58.1 \\
\hline
\end{tabular}

$* \%$ of total $\mathrm{N}$ in defatted endosperm flour. 


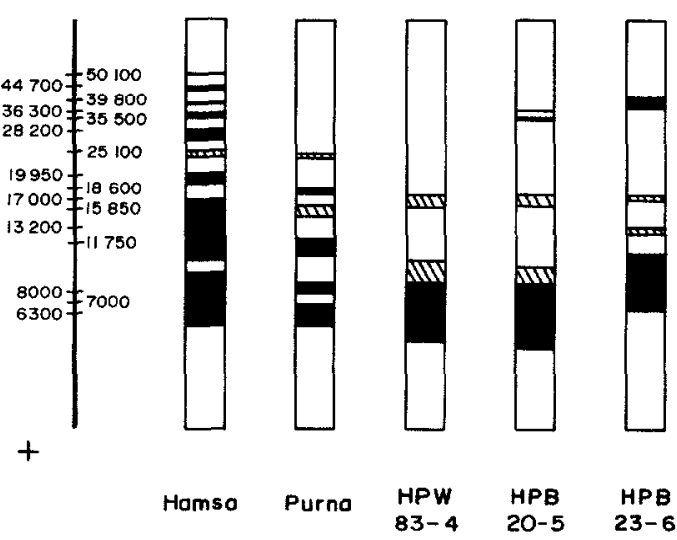

Fig. 1. SDS-PAGE patterns of albumin-globulin fraction (Fraction I) of finger millet varieties. Migration is from cathode (top) to anode (bottom).

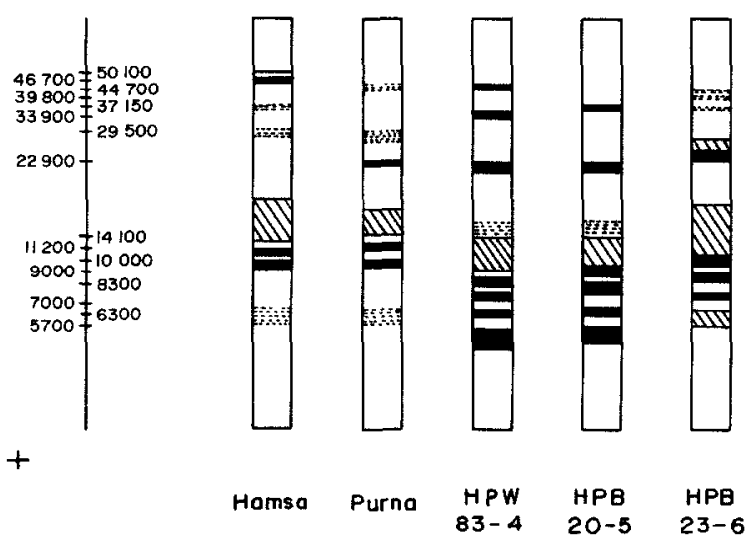

Fig. 2. SDS-PAGE patterns of prolamin fraction (Fraction II) of finger millet varieties. Migration is from cathode (top) to anode (bottom).
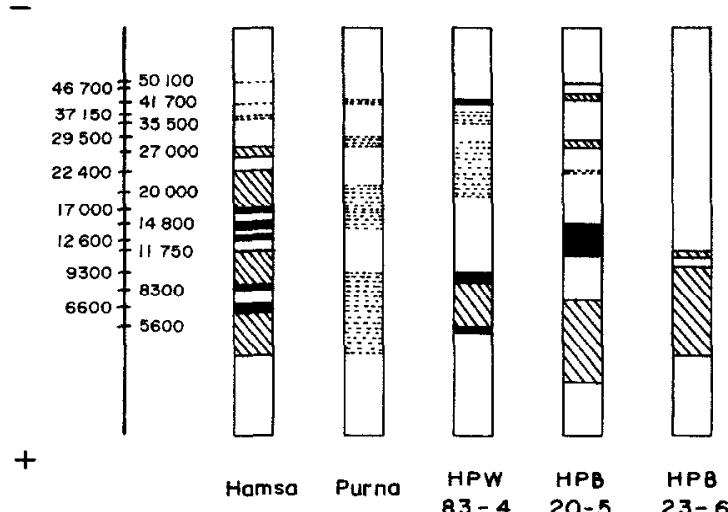

Fig. 3. SDS-PAGE patterns of glutelin fraction (Fraction III) of finger millet varieties. Migration is from cathode (top) to anode (bottom) distributions for the protein subunits. Accurate assignment of $\mathrm{MW}$ is difficult for those components yielding a diffusc protcin band. In such cases the MW is assigned to the most prominent band(s) within a diffuse band.

\section{Comparison of albumin globulin fraction}

Fig. 1 shows the SDS-PAGE patterns of the albuminglobulin (Fraction I) of finger millet meal solubilized by saline-distilled water extraction. Clear differences exist not only between the white grain (Hamsa) and browngrain(Purna) parent varieties, but also between the parents and hybrids derived by crossing these parental types (HPW 83-4, HPB 20-5 and HPB 23-6). Most notable differences are in the high $\mathrm{MW}$ components of the parent as well as the cross-bred varieties.

In the SDS-PAGE pattern of the Hamsa variety 9 protein bands were observed with $\mathrm{MW}$ of the protein subunits ranging from $8000-50000$. Low MW components were quantitatively more prominent as judged from the intensity of the protein bands, although the higher MW components were more numerous and distinct. The Purna variet y had fewer protein bands compared to the Hamsa variety and components with $\mathrm{MW}$ higher than 25000 were undetectable. Here again, the low MW subunits were more intense compared to the subunits with intermediate MW. The cross-bred varieties show only a few bands, unlike the patterns obtained with the parent varieties. In fact, HPW 83-4 shows an intense but diffuse band in the MW range 6000-11000 and a faint band of MW 17000, and no other band is visible in the electrophoretic pattern of this variety. The HPB 20-5 and HPB 23-6 varieties each show an intense band of low MW and a faint band of MW 17000 . Two sharp bands of MW 35500 and 37100 are observed in HPB 20-5 and an intense band of MW 39800 is seen in HPB 23-6.

\section{Comparison of prolamin fraction}

The SDS-PAGE patterns of the prolamin fraction (Fraction II) extracted by the isoPrOH-ME solvent show the least variations among the 5 finger millet varieties (Fig. 2) compared to the other 2 protein fractions. Polypeptides in the MW range 6000-10000 are present in almost all the varieties. Protein subunits of MWs 11200,22500 and 45000 are present in 3 of the 5 varieties, MWs 1410029500 and 37100 are present in 2 varieties, whereas, MWs 34000 and 46800 are present in only 1 of the 5 varieties of finger millet. Protein subunit of MW 50000 is present only in the Hamsa variety. HPB 20-5 lacks subunits of MW higher than 39800 .

\section{Comparison of glutelin fraction}

Fig. 3 shows the protein bands in the glutelin fraction (Fraction III) of the finger millet varieties extracted by borate-ME-SDS solvent system. Considerable variations in the protein patterns among the varieties is seen as in Fraction I protein. Fraction III protein of the Hamsa variety, which contained the highest number of subunits, resolved into $10-11$ bands in the MW range 6000-50000, while the HPB 20-5 variety had 6-7 protein subunits in this range. Purna and HPW 83-4 each had 4-5 subunits and HPB 23-6 had only 2-4 protein bands. It was difficult in the case of HPB 23-6 to establish the exact number of bands present because of the indistinct pattern obtained. The subunit of MW 50000 was present only in the Hamsa and HPB 20-5 varicties of finger millet. Purna and HPW 83-4 did not have protein subunits of MW higher than 41700 . The most notable feature of the electrophoretic 
pattern of HPB 23-6 is the absence of distinct protein components of MW higher than 12000 , although faint and diffuse high MW components are seen in the gel patterns. The low MW polypeptide components (MW $6000-8500$ ) are quantitatively the most important in the

Table 2. Amino acid composition of fraction I (albuminglobulin) ( $\mathrm{g} / 100 \mathrm{~g}$ of protein)

\begin{tabular}{lrrrrrrr}
\hline & & & \multicolumn{1}{c}{ HPW } & \multicolumn{1}{c}{ HPB } & \multicolumn{1}{c}{ HPB } & \\
& Hamsa & Purna & $83-4$ & $20-5$ & $23-6$ & Mean & Range \\
\hline Lys & 6.05 & 6.16 & 497 & 391 & 6.69 & 5.56 & $391-669$ \\
His & 240 & 232 & 2.22 & 1.58 & 2.55 & 2.21 & $1.58-255$ \\
Arg & 937 & 8.62 & 816 & 701 & 1165 & 8.96 & $701-1165$ \\
Asp & 768 & 859 & 7.63 & 1173 & 9.43 & 901 & $763-1173$ \\
Thr & 432 & 443 & 623 & 530 & 553 & 5.16 & $432-623$ \\
Ser & 506 & 582 & 787 & 769 & 579 & 645 & 506787 \\
Clu & 11.94 & 11.83 & 24.10 & 22.48 & 1313 & 1670 & $11.83-2410$ \\
Pro & 325 & 4.36 & 642 & 754 & 5.17 & 535 & $325-7.54$ \\
Gly & 525 & 6.27 & 662 & 8.29 & 4.55 & 6.20 & $4.55-8.29$ \\
Ala & 654 & 7.89 & 9.66 & 10.46 & 714 & 8.34 & $654-1046$ \\
Half-Cys & 2.95 & $021 *$ & 4.59 & 433 & 209 & 283 & $021-459$ \\
Val & 6.52 & 490 & 5.51 & 6.35 & 347 & 535 & $347-652$ \\
Met & trace & trace & 121 & 1.20 & 1.38 & 076 & $1.20-138$ \\
lle & 2.69 & 3.28 & 420 & 411 & 192 & 324 & $1.92-420$ \\
Leu & 5.25 & 628 & 8.10 & 8.14 & 4.14 & 6.40 & $4.14-814$ \\
Tyr & 226 & 247 & 4.01 & 4.48 & 204 & 305 & $2.04-448$ \\
Phe & 2.06 & 2.59 & 415 & 3.29 & 1.86 & 279 & $186-415$ \\
\hline
\end{tabular}

* Determined as cysteic acid. Cystine in the sample became oxidized to cysteic acid during the preparation of the hydrolysate and was eluted in the position of authentic cysteic acid.

Table 3. Amıno acid composition of fraction II (prolamın) (g/100 $\mathrm{g}$ of protein)

\begin{tabular}{lrrrrrrr}
\hline & & & HPW & HPB & HPB & & \\
& Hamsa & Purua & $83-4$ & $20-5$ & $23-6$ & Mean & Range \\
\hline Lys & 0.46 & 0.42 & 0.85 & 1.08 & 0.51 & 066 & $042-108$ \\
His & 188 & 203 & 396 & 5.03 & 2.50 & 308 & $188-503$ \\
Arg & 173 & 150 & 2.22 & 3.34 & 1.62 & 208 & $150-334$ \\
Asp & 450 & $\mathbf{4} 72$ & 4.54 & 3.94 & 420 & 438 & $394-4.72$ \\
Thr & 4.95 & 5.33 & 5.96 & 5.16 & 477 & 523 & $4.77-596$ \\
Ser & 5.71 & 7.11 & 7.18 & 606 & 5.43 & 6.30 & $5.43-718$ \\
Glu & 3193 & 32.75 & 33.67 & 3385 & 2899 & 32.24 & $2899-33.85$ \\
Pro & 879 & 9.09 & 13.07 & 1041 & 10.63 & 1040 & $8.79-13.07$ \\
Gly & 178 & 1.79 & 166 & 152 & 149 & 1.65 & $149-1.79$ \\
Ala & 6.05 & 695 & 742 & 6.99 & 6.41 & 6.76 & $6.41-742$ \\
Half-Cys & $134^{*}$ & $2.10^{*}$ & 2.92 & $t r a c e$ & trace & 1.27 & $134-2.92$ \\
Val & 7.52 & 749 & 10.02 & 6.73 & 6.03 & 756 & $603-1002$ \\
Met & 2.31 & 2.21 & 476 & 106 & 4.69 & 3.01 & $1.06-476$ \\
Ile & 5.09 & 549 & 520 & 529 & 4.59 & 5.13 & $4.59-549$ \\
Leu & 1228 & 1375 & 12.65 & 12.12 & 10.39 & 12.24 & $10.39-1375$ \\
Tyr & 453 & 501 & 5.03 & 4.21 & 4.48 & 4.65 & $4.21-503$ \\
Phe & 655 & 887 & 7.76 & 7.55 & 700 & 7.55 & $655-887$ \\
\hline
\end{tabular}

* as cysteic acid.

Table 4. Amino acid composition of fraction III (glutelin) $(\mathrm{g} / 100 \mathrm{~g}$ of protein)

\begin{tabular}{|c|c|c|c|c|c|c|c|}
\hline & Hamsa & Purna & $\begin{array}{c}\text { HPW } \\
83-4\end{array}$ & $\begin{array}{c}\text { HPB } \\
20-5\end{array}$ & $\begin{array}{l}\text { HPB } \\
23-6\end{array}$ & Mean & Range \\
\hline Lys & 7.22 & 6.80 & 900 & 940 & 6.04 & 2.69 & 6.04940 \\
\hline His & 3.16 & 478 & 4.40 & 4.04 & 3.03 & 388 & $3.03-478$ \\
\hline Arg & 864 & 760 & 998 & 1032 & 6.83 & 8.67 & $6.83-10 \quad 32$ \\
\hline Asp & 753 & 791 & 9.11 & 928 & 814 & 839 & $753-9.28$ \\
\hline Thr & 461 & 437 & 5.18 & 5.33 & 4.74 & 4.85 & $4.37-5.33$ \\
\hline Ser & 588 & 5.34 & 5.96 & 590 & 490 & 560 & $490-596$ \\
\hline Glu & 1829 & 20.99 & 2118 & 1980 & 14.84 & 1902 & $1484-21.18$ \\
\hline Pro & 5.60 & 627 & 826 & 960 & 451 & 6.85 & $451-960$ \\
\hline Gly & 4.38 & 448 & 462 & 414 & 379 & 4.29 & $379-467$ \\
\hline Ala & 5.92 & 645 & 732 & 652 & 6.09 & 6.46 & $592-732$ \\
\hline Half-Cys & 245 & $124^{*}$ & trace & trace & trace & 0.74 & $1.24-245$ \\
\hline Val & 4.79 & 652 & 568 & 4.24 & 5.38 & 532 & 4.246 .52 \\
\hline Met & 134 & 129 & 151 & 0.88 & 318 & 164 & $088-3.18$ \\
\hline Ile & 430 & 4.55 & 4.06 & 3.70 & 423 & 417 & $370-4.55$ \\
\hline Leu & 798 & 9.50 & 797 & 742 & 702 & 798 & $702-950$ \\
\hline Tyг & 2.98 & 391 & 3.36 & 273 & 3.32 & 326 & $273-3.91$ \\
\hline Phe & 4.29 & 4.78 & 487 & 340 & 485 & 444 & $3.40-487$ \\
\hline
\end{tabular}

* as cysteic acld. glutelin fraction of all the varieties and constitute the major components of the HPB 23-6 variety. The subunits with intermediate MW (14000-20000) are prominent in the Hamsa variety.

From the foregoing results it is evident that SDSPAGE is capable of resolving the protein subunits of finger millet varieties according to their molecular size and, therefore, can be employed to reveai the varietal differences in protein composition. It has been established from these studies that the $M W$ distribution of the protein subunits in the albumin-globulin, prolamin and glutelin fractions show many differences when the parental varieties are compared with the cross-bred varieties. Such differences are most noticeable in the albuminglobulin and glutelin fractions rather than in the prolamin fraction. Furthermore, variations in composition among the protein fractions are due mostly to differences in the distribution of the high MW and intermediate MW subunits of the glutelin fraction. Similar observations have been reported in the protein composition of barley varieties [5] and corn varieties [6]. Variations in the protein composition are more likely to be encountered in the prolamin and glutelin fractions which are the major storage proteins of cereal grains.

A few of the protein subunits, for example, the 50000 MW subunit of the Hamsa variety, occur in all the 3 protein fractions. It is possible that this is due to incomplete extraction of these protein components from the endosperm meal during successive extraction with the 3 solvent systems. It is also likely that these protein components have different solubility characteristics but the same $\mathrm{MW}$.

\section{Comparison of amino acid compositions}

The amino acid compositions of the 3 protein fractions from 5 varieties of finger millet are given in Tables 2-4. The amino acid compositions of the 3 fractions from the Hamsa and Purna varieties have already been reported in an earlier communication [3] but are reproduced here to facilitate a ready comparison with the other varieties.

The amino acid composition of Fraction I (albuminglobulin) of the finger millet varieties is shown in Table 2 along with mean values and range. The amino acid composition of the albumin-globulin fraction of all the 5 varieties is generally similar but with a few notable exceptions. HPW 83-4 and HPB 20-5 have lower amounts of lysine and arginine and higher amounts of glutamic acid, proline, leucine, tyrosine, phenylalanine and cystine compared to the other 3 varieties. In fact, glutamic acid levels are nearly double in HPW 83-4 and HPB 20-5 and the level of aspartic acid is also rather high in HPB 20-5. The isoleucine to leucine ratio in this protein fraction is $1: 2$. Compared to Fractions II and III, Fraction I contains glycine and cystine in higher amounts, whereas, glutamic acid, proline, leucine and phenylalanine are present in lower amounts.

The amino acid composition of Fraction II (prolamin) is given in Table 3. This fraction is characterized by very low levels of lysine, very high levels of glutamic acid, high levels of proline, valine, alanine, leucine, and phenylalanıne. The isoleucine to leucine ratio of Fraction II protein is ca 1:2.5. Arginine, glycine and aspartic acid are present in smaller amounts than in the other two fractions. The mean level of methionine is higher in the prolamin fraction than in either of the other two frac- 
tions. Fraction II protein of HPW 83-4 and HPB 23-6 are particularly rich in methionine and the levels of methionine in the whole seed protein of these 2 varieties of finger millet are also high [3].

It is seen from the amino acid composition of Fraction III (glutelin) protem presented in Table 4 that this fraction has the highest level of lysine of the 3 protein fractions. Histidine and arginine are also present in fairly high amounts. The proportions of glutamic acid, proline, leucine and phenylalanine are higher in the glutelin fraction than in the albumin-globulin fraction, but lower than in the prolamin fraction. HPB 23-6 has the lowest amounts of lysine, glutamic acid and proline, but the highest amount of methronine among the finger millet varieties. The isoleucine to leucine ratio is $1: 2$ in this fraction.

It is interesting to note that the amino acid compositions of the 3 protein fractions obtained from finger millet are similar to those of comparable fractions of corn [7] and sorghum [8]. The designation of Fraction II as the prolamin fraction in this study is justified due to the low levels of basic amino acids and high levels of glutamic acid, proline, leucine and phenylalanine found in this fraction. Similarly, the amino acid composition of Fraction III is that to be expected of the true glutelin fraction.

It is evident that the amino acid compositions of the individual protein fractions do show a few differences depending on the finger millet variety. Isolation of the individual protein bands in the 3 protein fractions and determination of their amino acid composition could lead to a better understanding of the changes in the amino acid composition resulting from the changes in the genotypes of the finger millet varieties.

\section{EXPERIMENTAL}

The 5 varietıes of finger millet were obtained from the Millet Research Centre, University of Agricultural Sciences, Bangalore, India. Defatted endosperm meal was prepared as described earlier [3].

Preparation of protem fractions. Extraction of the protein from the defatted endosperm flour by a modification of the Landry-Moureaux extraction procedure has been described [3]. In brief, $20 \mathrm{~g}$ of defatted flour was stirred with $100 \mathrm{ml}$ of $0.5 \mathrm{M} \mathrm{NaCl}$ for $2 \mathrm{hr}$. The residue was extracted with $100 \mathrm{ml}$ of $\mathrm{H}_{2} \mathrm{O}$ for $2 \mathrm{hr}$. $\mathrm{NaCl}$ and $\mathrm{H}_{2} \mathrm{O}$ extracts (Fraction I, albuminglobulin) were pooled The residue was then successively extracted with $100 \mathrm{ml}$ each of $70 \%$ is $\mathrm{PrOH}$ contanning $0.6 \%$ $\mathrm{ME}$ and borate buffer, $\mathrm{pH} 10$, containıng $0.5 \mathrm{M} \mathrm{NaCl}, 0.6 \%$
$\mathrm{ME}$ and $0.5 \%$ SDS to obtain the prolamin fraction (Fraction II) and glutelin fraction (Fraction III), respectively. The extracts were extensively dialysed against $\mathrm{H}_{2} \mathrm{O}$ in the cold and lyophilized.

The protein content in the individual lyophilized fractions was calculated by multiplying the $\mathrm{N}$ content as determined by micro-Kjeldahl method by the factor 6.25 .

Amino actd analyses. Known wts of proten fractions were hydrolysed in sealed tubes with $6 \mathrm{~N} \mathrm{HCl}$ for $22 \mathrm{hr}$ at $110^{\circ}$. $\mathrm{HCl}$ was removed under red. pres. at $45^{\prime \prime}$ and the residue dissolved in $0.2 \mathrm{M}$ citrate buffer, $\mathrm{pH} 2.2$, for amino acid analyses. Amino acid analyses were carried out by the method of ref. [9]

SDS PAGE of protein fractions. SDS-PAGE patterns of the individual protein fractions were obtained by electrophoresis in $10 \%$ polyacrylamide gel containing SDS following the method of ref. [10]. Proteins were reduced for $2 \mathrm{hr}$ at $37^{\circ}$ by incubation in $0.1 \mathrm{M} \mathrm{Pi}$ buffer, $\mathrm{pH} \mathrm{7,} \mathrm{containing} 1 \% \mathrm{ME}$ and $1 \% \mathrm{SDS}$. Electrophoresis was performed at a constant current of $8 \mathrm{~mA}$ per gel. The gels were stained for $18 \mathrm{hr}$ in $0.25 \%$ Coomassie Brilliant Blue and destained with a soln of $7.5 \% \mathrm{HOAc}$ and $5 \%$ $\mathrm{MeOH}$ in $\mathrm{H}_{2} \mathrm{O}$

Protein subunit MWs were determined by comparng the mobilities of the subunits with those of protens of known MW [10]. The proteins used as MW markers were cytochrome-c (MW 11700), trypsin (MW 23300), ovalbumın (MW 43000). catalase (monomer MW 60000) and serumalbumın(MW 68000). The marker proteins were prepared for electrophoresis in the same manner as the finger millet protein fractions.

Acknowledgements--We thank K. N. Mallanna, Plant Scientist (Millets). University of Agricultural Sciences, for finger millet samples and A. R. Prabhakar for technical assistance.

\section{REFER ENCES}

1. Mertz, E T., Bates, L. S. and Nelson. O. E. (1964) Science $145,279$.

2. Munck, L., Karlson, K. E and Hagberg, A. (1970) Sclence 168,985

3. Virupaksha, T. K, Ramachandra, G. and Nagaraju, D. (1975) J. Sci. Food. Agric. 26, 1237.

4. Landry, J. and Moureaux, T. (1970) Bull. Soc. Chim. Biol. 52, 1021 .

5. Singh, U. and Sastry, L. V. S. (1977) Cereal Chem. 54, 1.

6. Misra, P. S., Mertz, E. T. and Glover. D. V. (1976) Cereal Chem. 53, 705.

7. Misra, P. S., Mertz, E. T. and Glover, D. V. (1976) Cereal Chem. 53, 699 .

8. Virupaksha, T. K and Sastry, L. V. S. (1968) Agric. Food Chem. 16. 199

9. Spackman, D. H.. Stein, W. H. and Moore, S. (1958) Analyt. Chem. 30, 1190.

10. Weber, K. and Osborn, M. (1969) J Biol. Chem. 244, 4406. 